Arch. Histol. Cytol., Vol. 57, No. 4 (1994)

p. $415-425$

\title{
Phagocytotic Cells in the Fish Heart
}

\author{
Hiroaki Nakamura and Atsumi Shimozawa \\ Department of Anatomy, Dokkyo University School of Medicine, Mibu, Tochigi, Japan
}

Received May 20, 1994

\begin{abstract}
Summary. Comparatively little is known about hostdefense activities in the fish heart. Investigations showed that intraperitoneally injected carbon particles are actively taken up by the cardiac endothelial cells of the medaka Oryzias latipes, but less so by those of the goldfish Carassius auratus and lemon tetra Hyphessobrycon pulchripinnis. (In vitro experiments confirmed these species differences in endocytic activities by these cells.) Electron microscopy revealed that endothelial cells of the medaka atrium have large cytoplasm with many organelles, and ingested carbon particles were observed within phagosomes of cardiac endothelial cells even at $4^{\circ} \mathrm{C}$. Phagocytic cells, which apparently reside in the heart, were found in all the species examined. These cells were located on the endothelial cells and developed cytoplasmic processes extending toward the heart lumen and/or the intercellular spaces of the endothelial cells. The heart with its resident phagocytes is proposed to function as a host defense organ - at least in certain fish species.
\end{abstract}

The heart functions both as the main organ of the circulatory system and as an important endocrine organ because of its secretion of atrial natriuretic polypeptide. These two defferent functions of the heart have been studied intensively from ectothermic vertebrates to mammals. Moreover, in invertebrates such as molluscs and ectotherms such as fish, host defense activities of the heart have been recognized for many years, although the data concerning this aspect of the heart are still fragmental.

In molluscs, amebocytes, which correspond to macrophages of vertebrates, may be produced in the wall of the saccular portion of the kidney that borders the pericardium (LIE et al., 1975).

In fish, the uptake of intraperitoneally injected carbon particles by the endcardium has been observed in the cunner (MACKMULL and MiCHELS, 1932), goldfish (MORI, 1980), plaice (FERGUSON, 1975; ELLIS et al., 1976), swordtail and coalfish (LEKNES, 1987).
In this report we demonstrate that two cellular elements in teleost heart, i.e., endothelial and residentphagocytic, are capable of the endocytotic elimination of foreign bodies.

\section{MATERIALS AND METHODS}

\section{Fish}

Adult medaka Oryzias latipes, goldfish Carassius auratus, and lemon tetra Hyphessobrycon pulchripinnis of both sexes were used. They were kept in plastic vessels $(17 \times 28 \times 18 \mathrm{~cm})$ containing aged tap water at a temperature of about $23^{\circ} \mathrm{C}$ and fed Tetra-Min (Tetra Werke, Germany) daily.

In vivo assay of endocytosis

A $1 \%$ dilution (using $0.75 \% \mathrm{NaCl}$ ) of India ink (Pelikan AG, Germany) was injected intraperitoneally using a disposable insulin syringe with a 28 gauge needle. We injected $0.04 \mathrm{ml} / \mathrm{g}$ body weight.

Only in the medaka was a $10 \%$ dilution (using $0.75 \%$ $\mathrm{NaCl}$ ) of yellow-green fluorescent latex microspheres (FluoSpheres, Molecular Probes, Inc., USA), about 2 $\mu \mathrm{m}$ in diameter, or a $10 \%$ suspension of formalinized sheep red blood cells (SRBCs, Cappel, USA) injected in the same manner as the India ink.

\section{Test for endocytosis in vitro}

Hearts were dissected out from 3 fish of each species previously anesthetized with MS 222 (Sankyo Co., Ltd, Japan). They were cut open with a razor and rinsed with DM-170 tissue culture medium (Kyokuto Pharmaceutical Industrial Co., Ltd, Japan) and then incubated in a $1 \%$ dilution of India ink in the same medium for $2 \mathrm{~h}$ at $25^{\circ} \mathrm{C}$. During incubation, the heart contracted continuously. Carbon uptake was observed light microscopically in JB-4 plastic sections as mentioned below. 


\section{Light microscopy}

One or 2 days after injection, 5 fish of each species were fixed in toto with $2 \%$ paraformaldehyde and $2.5 \%$ glutaraldehyde in $0.1 \mathrm{M}$ phosphate buffer $(\mathrm{pH}$ 7.2). The heart, spleen, kidney and liver were dissected out and dehydrated in graded concentrations of ethanol and embedded in JB-4 plastic resin (Polysciences, Inc. USA). Sections were stained with hematoxylin and eosin or with toluidine blue.

For the medaka alone, whole body cross sections were also made from paraffin embedded specimens at several intervals after carbon injection at $4^{\circ} \mathrm{C}, 10^{\circ} \mathrm{C}$, and $23^{\circ} \mathrm{C}$. The liver, spleen, kidney and thymus were histologically observed and the location of carbon uptake compared with that of the heart and its associated tissues.

The location of intraperitoneally injected fluorescent latex microspheres was examined with an Olympus BHS microscope equipped with epifluorescence optics.

\section{Electron microscopy}

Hearts were fixed with $2 \%$ paraformaldehyde and $2.5 \%$ glutaraldehyde in $0.1 \mathrm{M}$ phosphate buffer $(\mathrm{pH}$
7.2) for $12 \mathrm{~h}$ at $4^{\circ} \mathrm{C}$, postfixed with $1 \%$ osmium tetroxide in the same buffer for $2 \mathrm{~h}$ at $0^{\circ} \mathrm{C}$, dehydrated and embedded in Quetol 651 epoxy resin (KusHIDA 1974). Sections were cut on a Porter-Blum MT-2 ultramicrotome, stained with uranyl acetate and lead citrate and examined with a JEOL $100 \mathrm{~B}$ electron microscope operated at $80 \mathrm{kV}$.

\section{RESULT}

\section{Histology of endocardial endothelium}

The heart is located in the ventral part of the fish body just posterior to the gills. It is composed of a thin-walled atrium and thick-walled ventricle. Cardiac muscles develop many trabeculae, giving the tissues a spongy appearance, especially in the ventricle.

The endocardial endothelium of the goldfish and lemon tetra was very thin, consisting of a simple layer of squamous cells (Fig. 1a, b). When observing a single cell, we found it to be rather thick in the nuclear region and attenuated toward the periphery. Cytoplasmic organelles were poorly developed although electron lucent vacuoles and dense bodies were usu-

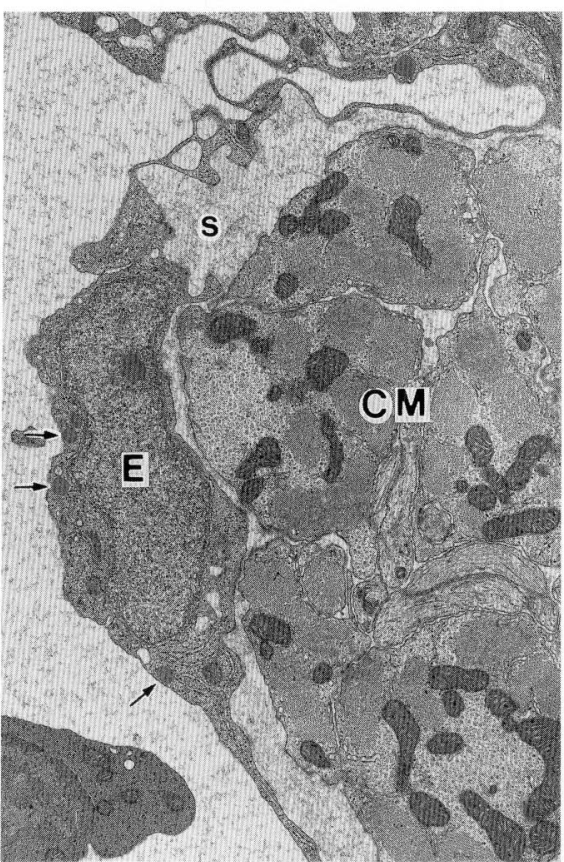

a

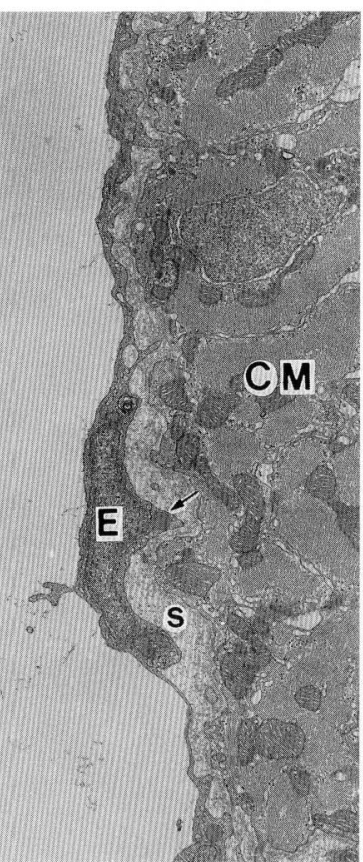

b

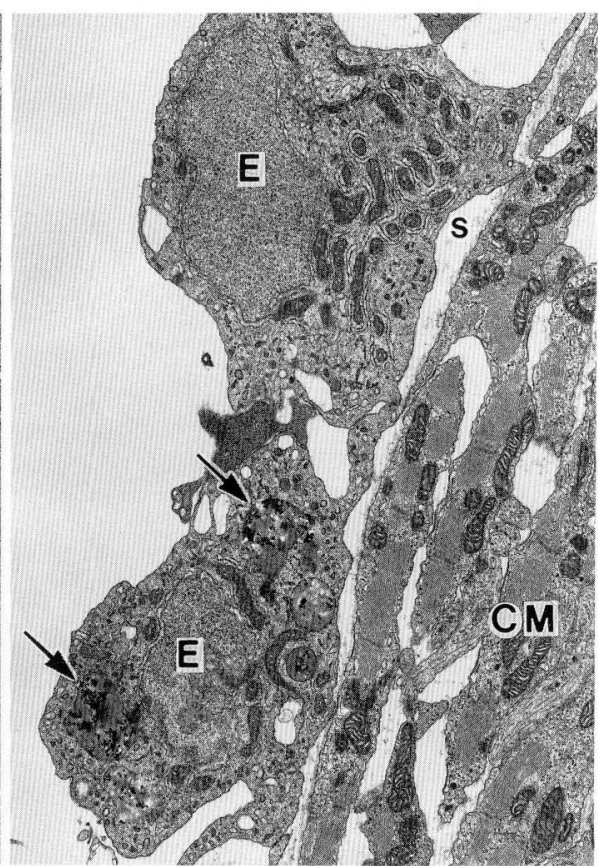

c

Fig. 1. Electron micrographs of the endocardium of goldfish (a), lemon tetra (b) and medaka (c) 2 days after intraperitoneal injection of carbon particles. The cardiac endothelial cells $(E)$ of the goldfish and lemon tetra have hardly taken up carbon particles. Dense-bodies (arrows in $\mathbf{a}, \mathbf{b}$ ) are sometimes encountered. Cardiac endothelial cells of the medaka have actively taken up carbon particles (arrows in c). $C M$ cardiac muscle, $s$ subendothelial space. $\times 6,200$ 
ally observed. Desmosome-like junctions were always recognized between neighboring endothelial cells. We never observed any evidence of phagocytosis by cardiac endothelial cells in uninjected fish.

Cardiac endothelial cells of the medaka differed markedly from those of the goldfish and lemon tetra. Especially in the atrium, endothelial cells had a large amount of cytoplasm with a single round or somewhat irregular nucleus, prominent phagosomes, welldeveloped Golgi complex and numerous tubular plasmalemmal vesicles (Fig. 1c). Similar organelles were observed within the ventricular endothelial cells; however, their cytoplasm was smaller and thinner than those of the atrium.

A basement membrane was not developed beneath the cardiac endothelial cells in any of the species examined, although collagenous fibers of varying amounts were always observed in the subendotheial spaces (Fig. 1a-c).

\section{In vivo uptake of carbon particles}

After intraperitoneal injection of carbon particles, the kidney and spleen became blackened because of their extensive uptake of carbon particles. The heart of the medaka also became blackened while that of the goldfish and lemon tetra remained reddish in color. No carbon uptake was observed in the liver or thymus (Table 1).

The degree of the endocytosis by endocardial cells differed among the species (Fig. 1a-c). In the medaka, considerable amounts of carbon particles were endocytosed by cardiac endothelial cells even 15 min after injection. Almost all the endothelial cells were black- ened with carbon particles which were incorporated within the cytoplasmic vacuoles or phagolysosomes. Carbon uptake was more inconspicuous in the endothelial cells of the bulbus arteriosus. In the goldfish and lomon tetra heart, the uptake of carbon particles by endothelial cells was inconspicuous or absent. Cells which took up carbon particles were rarely observed in the cells 1-2 days after injection. Most of the cells were seemingly free of carbon, although in the lemon tetra, a minute uptake was revealed by electron microscopy (Fig. 2).

The effects of temperature on carbon uptake by the cardiac endothelial cells and cells of other immune organs were studied in the medaka (Table 1). The kidney and spleen appeared to function as primary phagocytic organs in this species, and cardiac endothelial cells as well as phagocytes in the heart also showed an active uptake of carbon particles even at low temperatures of $4^{\circ} \mathrm{C}$ and $10^{\circ} \mathrm{C}$ (Fig. 3).

\section{In vivo uptake of latex microspheres and SRBC by medaka endocardium}

Fluorescence microscopy demonstrated that latex microspheres, about $2 \mu \mathrm{m}$ in diameter, were present within cardiac endothelial cells 2 days after they were introduced intraperitoneally. However, the number of the cells that phagocytosed latex microspheres was low. Latex microspheres were also present in phagocytes of the heart (Fig. 4a,b). SRBCs were also taken up by phagocytes resting on the cardiac endothelial cells, while the latter cells were not involved in the phagocytosis of SRBCs (Figs. 5, 6).

Table 1. Distribution of intraperitoneally injected carbon particles in various organs of the medaka (at $4^{\circ} \mathrm{C}, 10^{\circ} \mathrm{C}$ and $23^{\circ} \mathrm{C}$ ), goldfish and lemon tetra (at $23^{\circ} \mathrm{C}$ ).

\begin{tabular}{lrlrrrrr}
\hline & & & Heart & Spleen & Kidney & Thymus & Liver \\
\hline Medaka $^{1)}$ & $23^{\circ} \mathrm{C}$ & $15 \mathrm{~min}$ & $++{ }^{3)}$ & ++ & + & - & - \\
& & $30 \mathrm{~min}$ & $++{ }^{3)}$ & ++ & + & - & - \\
& & $90 \mathrm{~min}$ & $++^{3)}$ & ++ & ++ & - & - \\
& & $24 \mathrm{~h}$ & $+++{ }^{3)}$ & +++ & +++ & - & - \\
& $4^{\circ} \mathrm{C}$ & $15 \mathrm{~min}$ & $-{ }^{3)}$ & \pm & - & - & - \\
& & $18 \mathrm{~h}$ & $++{ }^{3)}$ & ++ & ++ & - & - \\
Goldfish $^{2)}$ & $10^{\circ} \mathrm{C}$ & $15 \mathrm{~min}$ & $+{ }^{3)}$ & + & \pm & - & - \\
Lemon tetra $^{2)}$ & $23^{\circ} \mathrm{C}$ & $24 \mathrm{~h}$ & $+{ }^{4)}$ & +++ & +++ & $\mathrm{ND}$ & - \\
\hline
\end{tabular}

${ }^{1)}$ : observed in paraffin sections, ${ }^{2)}$ : observed in plastic sections, ${ }^{3)}$ : carbon found within both cardiac endothelial cells and cardiac resident phagocytes, ${ }^{4)}$ : carbon found within cardiac resident phagocytes,,,,,++++++ \pm- : the amount of incorporated carbon, ND: not done. 

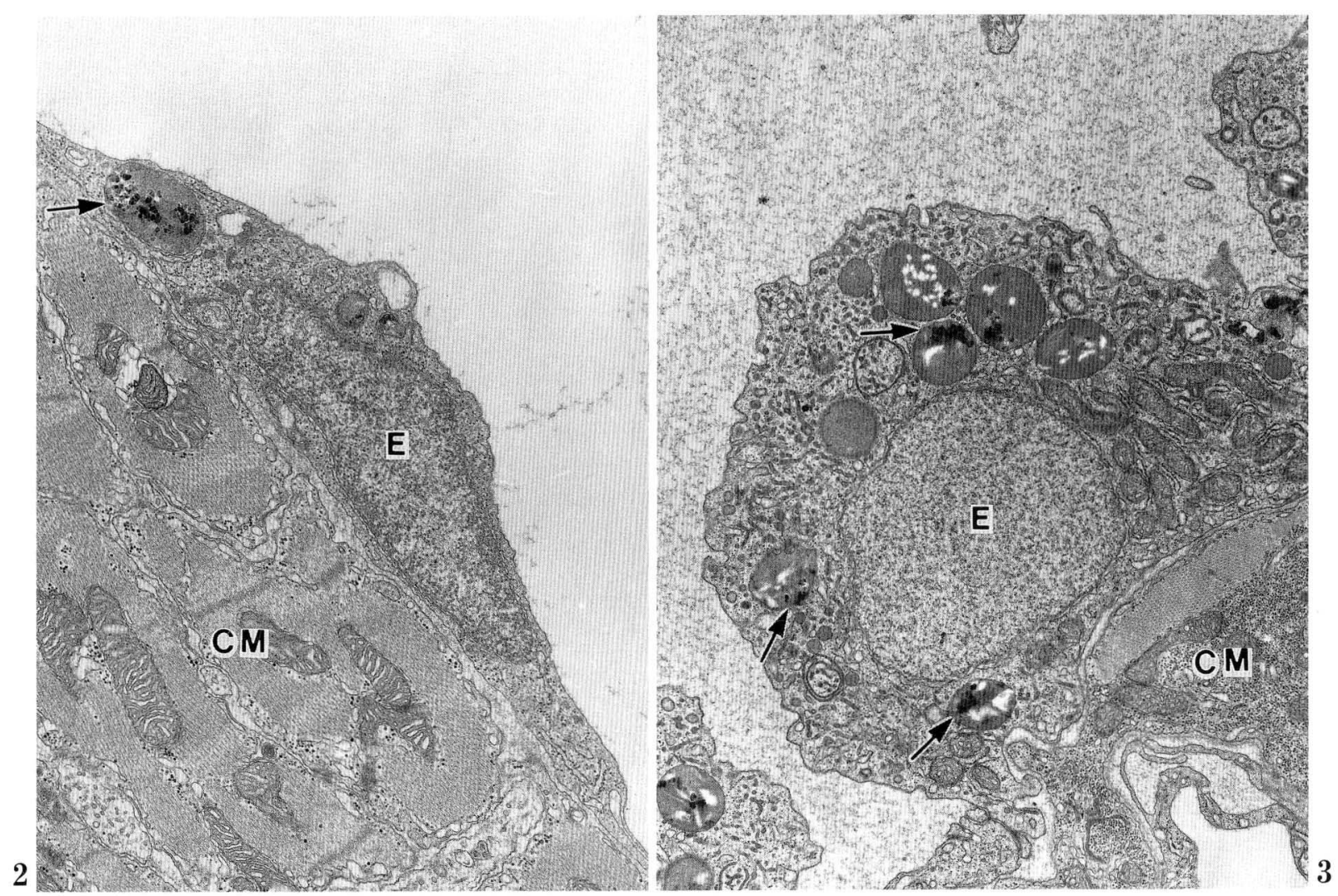

Fig. 2. Electron micrograph of lemon tetra cardiac endothelial cells $(E)$. Minute uptake of carbon particles (arrow) is occasionally noted. Two days after carbon injection. $C M$ cardiac muscle. $\times 15,500$

Fig. 3. Electron micrograph of medaka cardiac endothelial cell $(E)$ after carbon injection at $4^{\circ} \mathrm{C}$. Arrows indicate ingested carbon particles in phagosome-like bodies. $C M$ cardiac muscle. $\times 8,350$

\section{In vitro uptake of carbon particles}

Endocytotic activities of fish endocardium were studied histologically after $2 \mathrm{~h}$ incubation of isolated hearts in tissue culture media containing $1 \%$ India ink. Carbon particles were actively taken up by cardiac endothelial cells of the medaka, whereas essentially no particles were endocytosed by those of the lemon tetra or goldfish; carbon-laden phagocytes were apparent in the heart of the medaka and goldfish (Fig. 7a-c).

\section{Resident phagocytes}

Light and electron microscopic examination revealed randomly distributed cells with irregular contours resting on the cardiac endothelial cells of all the species examined (Figs. 8, 9, 10a-d). The cells, often extending cytoplasmic processes toward the lumen and/or intercellular spaces of endothelial cells, appeared to be resting and not circulating in the blood stream. These cells possessed an oval or somewhat irregularly shaped nucleus, phagosomes and vacuoles varying in diameter and shape, prominent Goigi complex, many pinocytotic vesicles, free ribosomes and mitochondria. Phagocytosed erythrocytes were frequently found in their cytoplasm (Fig. 9). Carbon particles were incorporated within the phagosomes of these cells after intraperitoneal injection. Most of these cells developed microvillus-like processes at the contact site with underlying endothelial cells which also developed cytoplasmic processes toward them. (Figs. 9, 10). From these observations, we identified these cells as cardiac resident phagocytes. Some of the cells developed long cytoplasmic processes of varying number and shape extending toward the lumen.

Species differences were recognized in the morphology of the cardiac resident phagocytes. In the goldfish, large vacuoles were prominent, at times occuping a large part of their cytoplasm (Fig. 10c), while in the medaka, most vacuoles were small and phagosomes were rather prominent. In the goldfish, tubular bodies were occasionally found in the cytoplasm (Fig. 10d), although typical worm-like bodies 

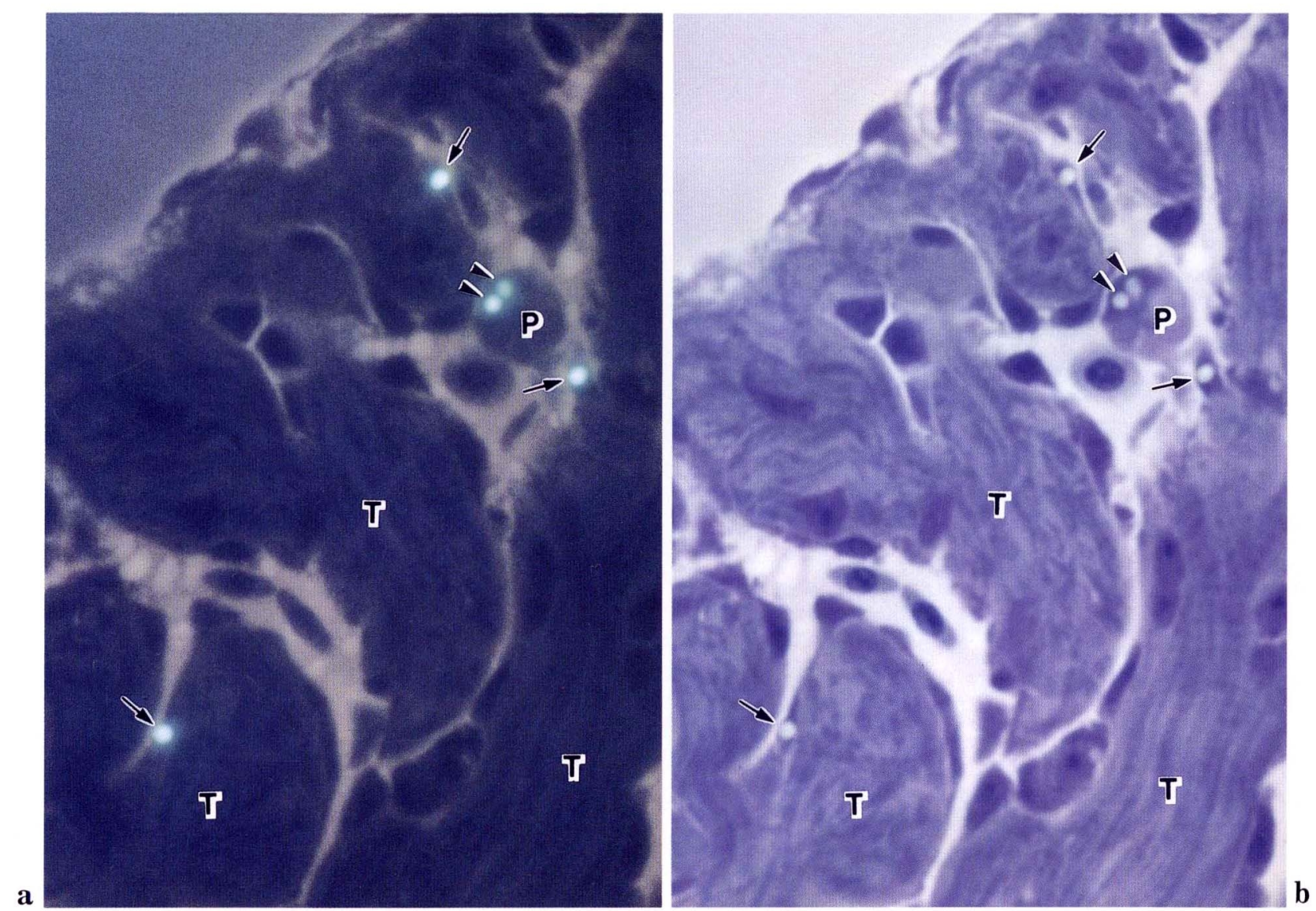

Fig. 4 a. Fluorescent micrograph of a plastic section of the medaka heart 2 days after intraperitoneal injection of latex FluoSpheres ( $2 \mu \mathrm{m}$ in diameter). b. Light micrograph of the identical field as in a. Arrows indicate latex FluoSpheres present in cardiac endothelial cells, and arrowheads indicate those in cardiac resident phagocytes. Stained with toluidine blue. $P$ phagocytes, $T$ trabeculae. $\times 1,350$

characteristic of mammalian Kupffer cells were not identified. In all three species we found no special cellular junctions between the phagocytes and endothelial cells.

\section{DISCUSSION}

Endothelial cells of blood vessels generally line not only their inner surfaces but also have many other functions; their morphology varies greatly in blood capillaries. Endothelial cells of large blood vessels are usually flat in their major cytoplasmic areas except the nuclear region, in accordance with the morphology of the cardiac endothelium in the rat (MELAX and LEESON, 1967). Recently, the cardiac endothelial cells have been proposed to modulate the functions of subjacent myocardium by releasing inotropic substances (BRUTSAERT, 1989; SMITH et al., 1991; TAKANASHI and ENDOH, 1991; BRUTSAERT and ANDRIES, 1992), and this effect was correlated with the characteristic shape and cytoskeleton organization of the cells in question (ANDRIES and BRUTSAERT, 1993).

The endothelial cells of the medaka atrium in this study were large and rich with organelles, while those of the goldfish and lemon tetra contained some densebodies and electron-lucent vacuoles. These features of medaka cardiac endothelial cells, in which a release of inotropic substances is unknown yet, markedly differed from the corresponding cells in mammals, as these contain only scanty organelles. LEMANSKI et al. (1975) previously noticed that the medaka endocardium comprised a thick, continuous cell layer with well-developed cytoplasmic organelles, and suggested a high metabolic activity for it. 


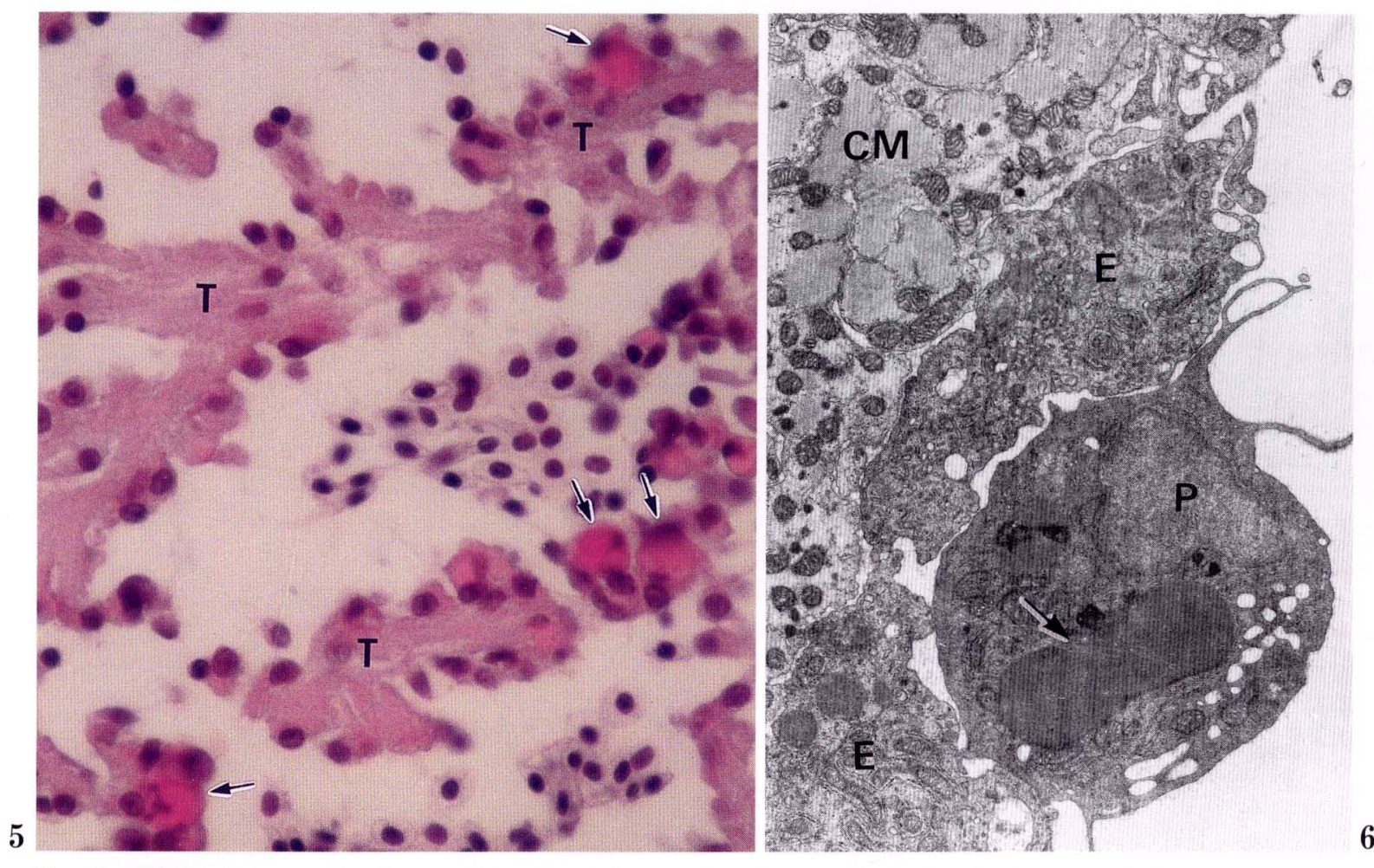

Fig. 5. Light micrograph of a medaka heart 1 day after intraperitoneal injection of a $10 \%$ suspension of formalinized SRBCs. Arrows indicate SRBC-laden phagocytes in the heart. $T$ trabeculae. $\times 840$

Fig. 6. Electron micrograph of a medaka heart 2 days after intraperitoneal injection of a $10 \%$ suspension of formalinized SRBCs. Ingested SRBC (arrow) are observed in a cardiac resident phagocyte $(P)$. Cardiac endothelial cells $(E)$ are not involved in the phagocytosis of SRBCs. $C M$ cardiac muscle. $\times 5,730$

The present study demonstrated the active uptake of carbon particles by medaka cardiac endothelial cells. In plaice Pleuronectes platessa, similar observations of carbon uptake have been reported in the endothelial cells of its heart (FERGUSON, 1975; ELLIS et al., 1976). In contrast, no carbon uptake was recognized in the heart of the carp Cyprinus carpio and the rosy barb Barbus conchonius (LAMERs and PARMEnTIER, 1985), similar to our observations in the goldfish and lemon tetra.

In ectothermal animals, the ambient temperature is one of the essential factors that affect their immunological activities. In the carp Cyprinus carpio, Avtalion et al. (1973) detected no antibody titers by passive hemagglutination, as long as the fish were kept at low temperature. However, they found that the phagocytosis occurs at low temperature. In the present study, medaka cardiac endothelial cells and cardiac resident phagocytes were revealed to endocytose carbon particles even at $4^{\circ} \mathrm{C}$ although the rate of the endocytosis was markedly decreased. In mammals, NAITO et al. (1991) noticed that the receptor- mediated endocytosis of acetylated low-density lipoprotein by bovine macrophages occurs efficiently at $37^{\circ} \mathrm{C}$ but not at $4^{\circ} \mathrm{C}$ in vitro. Cells of mammals that are homeothermal may be animated at around their optimum temperature of $37^{\circ} \mathrm{C}$, while cells of eurythermal fish may function over a wide range of temperatures. The difference of endocytotic activity between bovine and fish macrophages at low temperature may relate to such differing natures of the cells. The medaka can survive even at $0^{\circ} \mathrm{C}$, although their basal metabolic rate is known to be markedly decreased. This may explain the slow uptake of carbon particles at $4^{\circ} \mathrm{C}$. Further studies are needed to detect and characterize scavenger receptors in fish macrophages.

The present study utilizing the fluorescent microscope, showed minute phagocytotic activity of the cardiac endothelial cells for latex microspheres (2 $\mu \mathrm{m}$ in diameter), while it failed to demonstrate their phagocytosis of SRBCs. Difference in sizes and/or surface materials between latex microspheres and SRBCs might be causally related to this different attitude of the cells. FERGUSON (1975) described the 


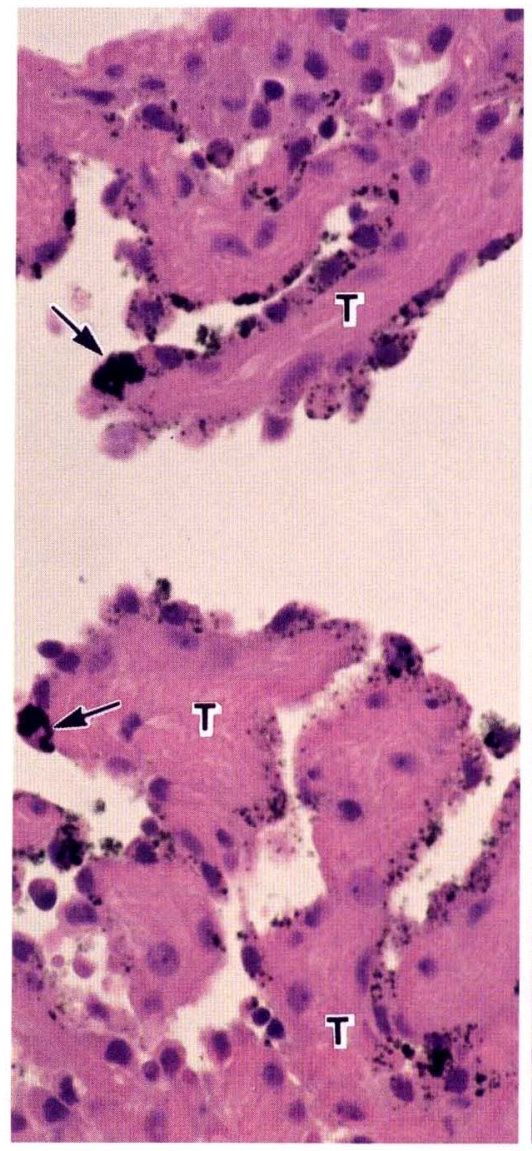

a

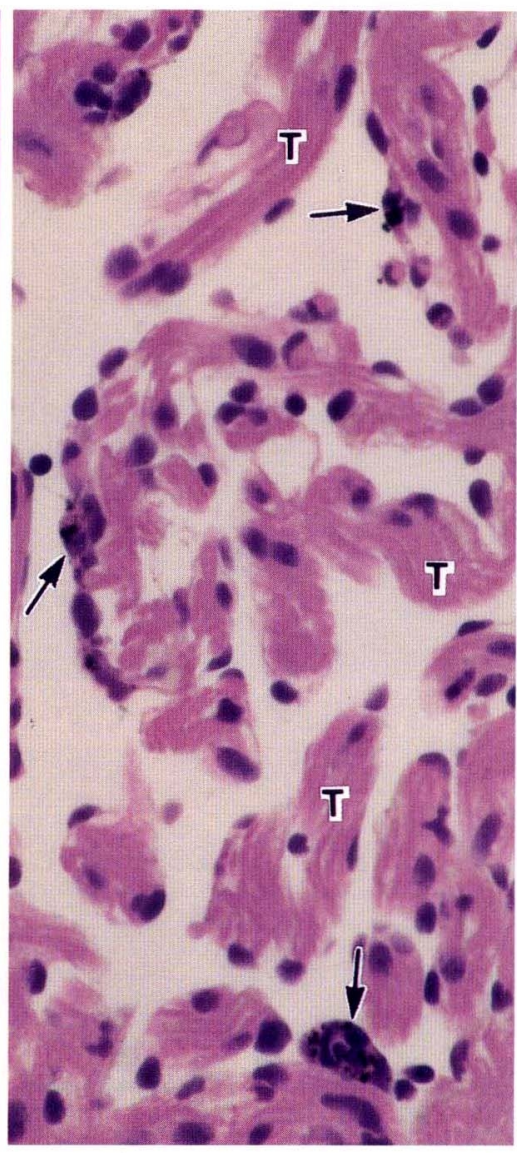

b

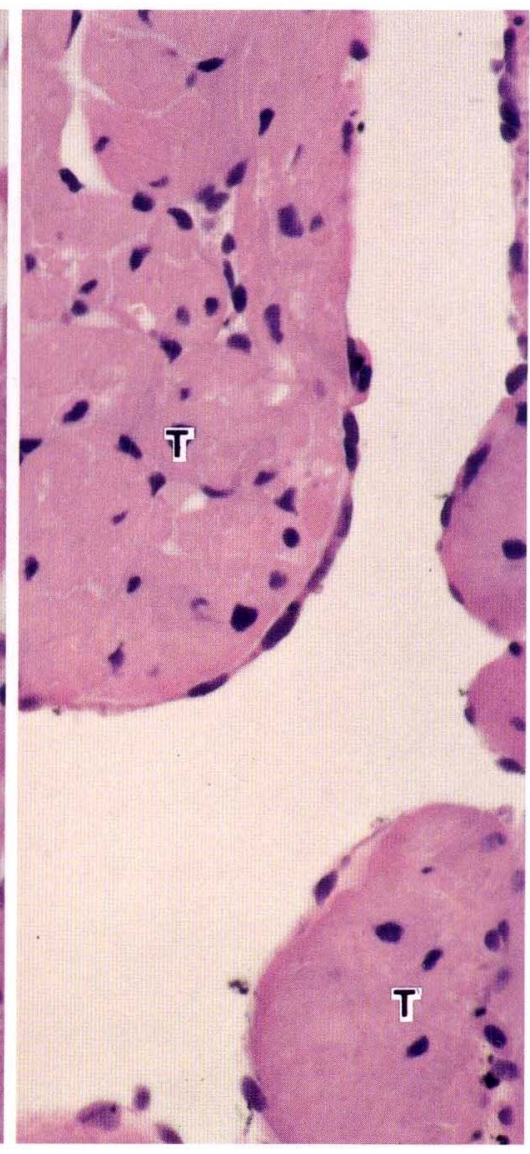

c

Fig. 7. Light micrographs of a plastic section of the heart of the medaka (a), goldfish (b) and lemon tetra (c) after organotypical incubation in the tissue culture medium DM-170 containing 1\% of India ink (carbon particles) for $2 \mathrm{~h}$ at $25^{\circ} \mathrm{C}$. Most cardiac endothelial cells of the medaka are blackened with ingested carbon while no significant uptake can be observed in goldfish and lemon tetra. Arrows in a, b indicate carbon-laden resident phagocytes. $T$ trabeculae. $\times 600$

phagocytosis of yeast particles by cardiac endothelial cells of the plaice. Studies concerning endocytic activities of foreign materials by fish cardiac endothelial cells are still limited in scope, and only light microscopical observations are available concerning this phenomenon (FERGUSON, 1975). In mammals, when large foreign bodies such as erythrocytes are administered, only macrophages are involved in phagocytosis, while the endothelial and reticular cells show no such activity (FUJITA, 1978). TEM and SEM observations are needed to demonstrate the presence or absence of phagocytotic activity of fish cardiac endothelial cells.

The passage of particulate matter from the peritoneal cavity into the lymph vessels of the diaphragm has been observed histologically in the rat (SIMER, 1934) and Japanese monkey (OyA et al., 1993); in fish, however, no studies exist on the lymphatic vessels which drain peritoneal fluids and/or cells. The question of how injected carbon particles reach the endocardium therefore remains to be answered.

In vitro experiments of carbon uptake by cardiac endothelial cells could be carrid out under controlled conditions of the outer milieu of the cells, but it is difficult to establish suitable incubation conditions for these cells. Results of current in vitro experiments using the hearts of the medaka, goldfish and lemon tetra were essentially in accordance with those of in vivo experiments although the time for carbon uptake was shorter in the in vitro experiments $(2 \mathrm{~h})$ than that of in vivo experiments (1-2 days). Improvement of incubation conditions is needed to maintain organs for a longer time in the culture media so that the comparison of the in vitro and in vivo findings 

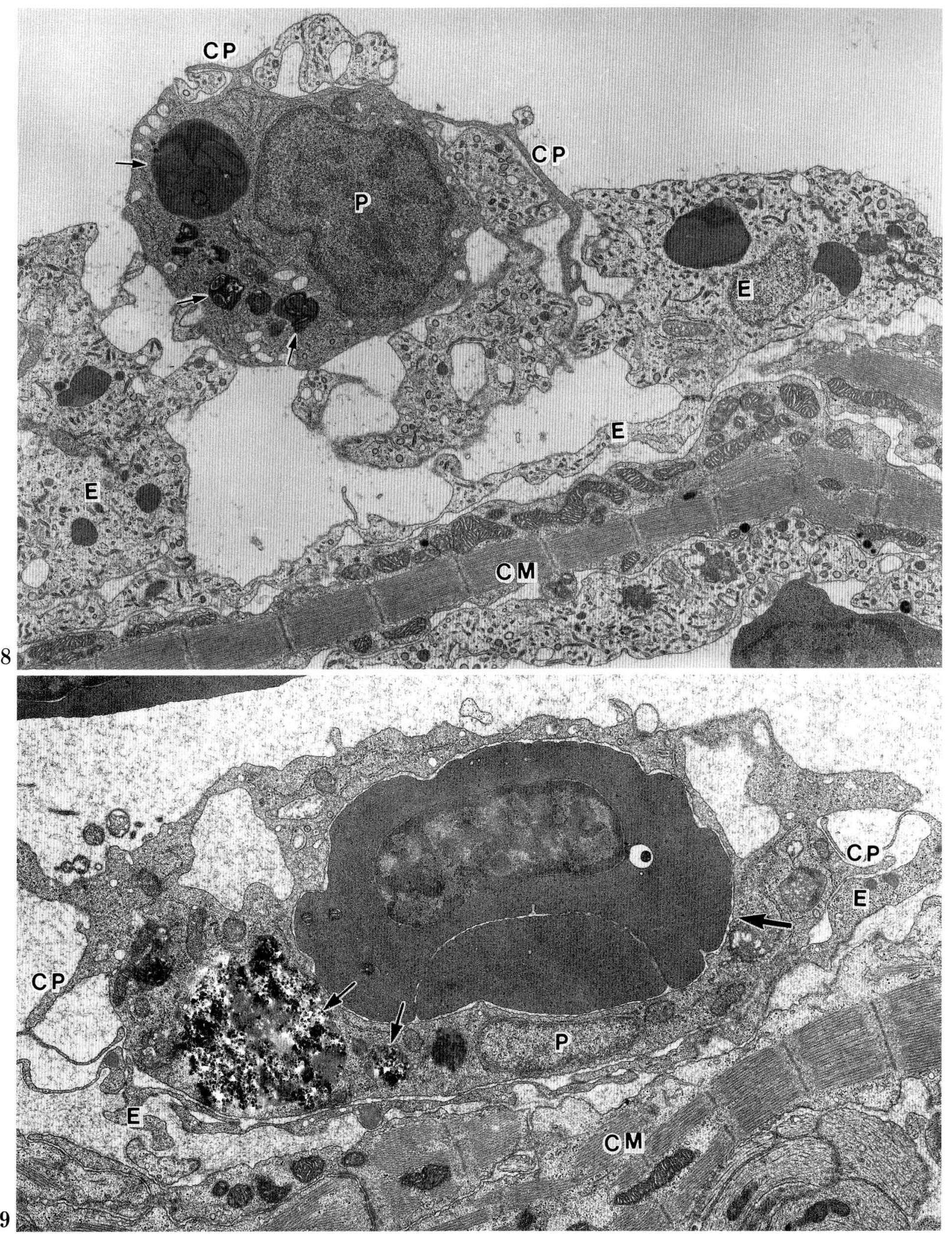

Fig. 8. Electron micrograph of normal medaka endocardium. Cardiac resident phagocyte $(P)$ with heterogeneous inclusions (arrows) and cytoplasmic processes $(C P)$. E cardiac endothelial cell. $\times 8,400$

Fig. 9. Electron micrograph of cardiac resident phagocytes $(P)$ of the goldfish. Phagocytosed erythrocytes (large arrow) and ingested carbon particles (small arrows) are observed. $C M$ cardiac muscle, $C P$ cytoplasmic process, $E$ cardiac endothelial cell. $\times 10,500$ 

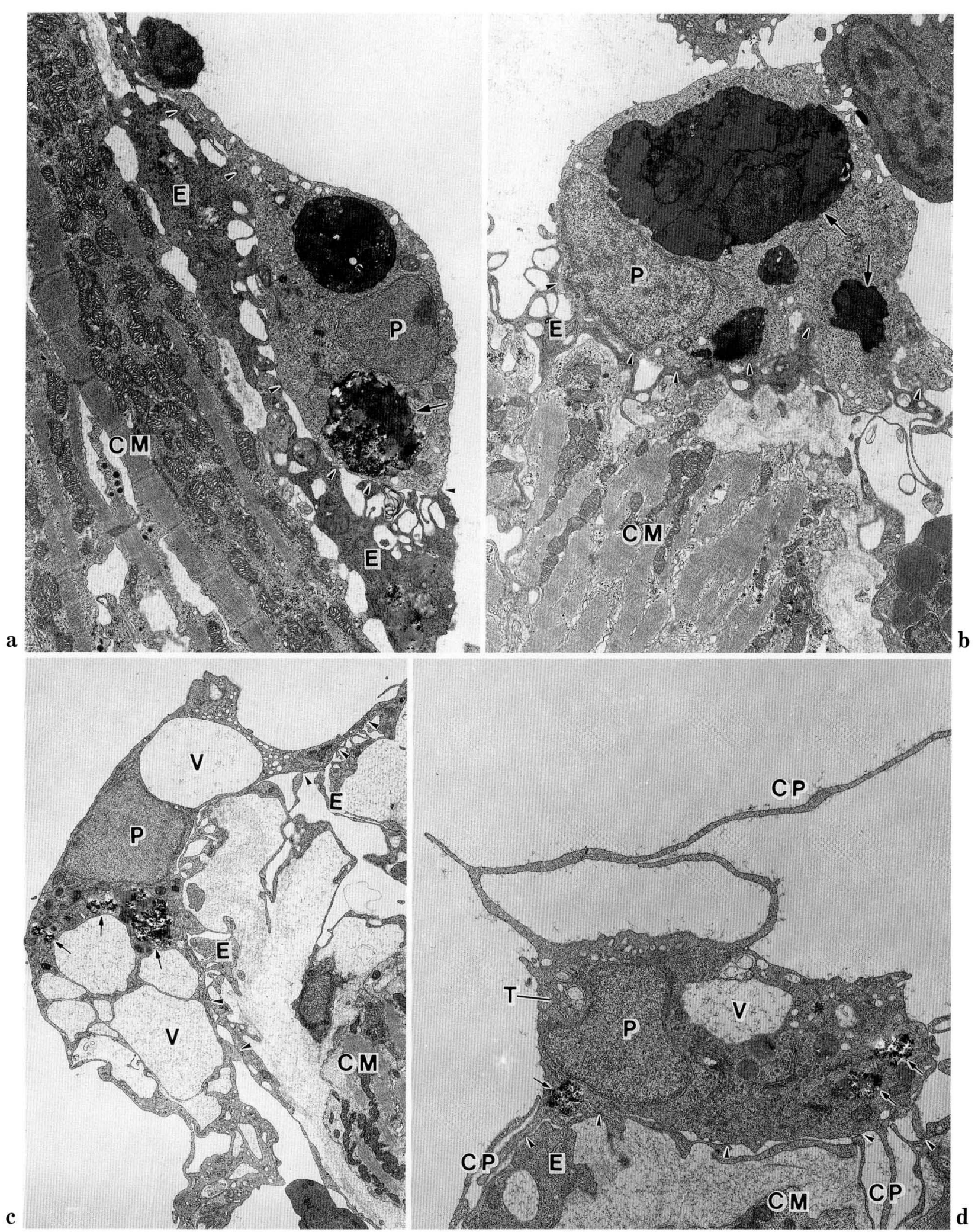

Fig. 10. Various forms of cardiac resident phagocytes $(P)$ of the medaka (a), lemon tetra (b) and goldfish (c, d). They are closely attached (arrowheads) to endothelial cells (E). Arrows indicate various appearances of phagosomes and ingested carbon particles. Large vacuoles $(V)$ are characteristic of goldfish resident phagocytes (c). Cells with well-developed cytoplasmic processes $(C P)$ are commonly observed. $C M$ cardiac muscle, $T$ tubular bodies. a, b: $\times 6,200, \mathrm{c}: \times 4,150, \mathrm{~d}: \times 8,350$ 
can be more precisely done.

Phagocytotic cells residing in the subendocardial space were observed in other fish species (OVERSTREET and Thulin, 1989; NAKAmura et al., 1993) and the bullfrog (KISCH, 1962). However, the presence of resident phagocytes that are in contact with the blood stream in the fish heart has been demonstrated here for the first time. Free macrophages and melano-macrophage centers that are characteristic of fish immune organs occurred in the ventricle of Plectropomus leopardus in response to infection by the blood fluke Pearsonellum conventum (OvERSTREET and Thulin, 1989) and in the heart of the normal medaka (NAKAMURA et al., 1993). ElLIS et al. (1976) regarded the phagocytic endocardial cells of plaice as phagocytic reticular cells, observing that the cells became spherical, freed from the endocardial lining after carbon phagocytosis and became macrophages which finally lodged in melano-macrophage centers in the kidney and spleen. We have not observed such a transformation of the cardiac endothelial cells into macrophage-like cells. The cardiac resident phagocytes were clearly different from cardiac endothelial cells because they had none of the intercellular junctions which characterize the endothelial cells, and which comprised a simple cell layer on the myocardium. Moreover, the cardiac resident phagocytes were morphologically different from the cardiac endothelial cells and also from fish monocytes in the blood stream (WEINREB, 1963; NAKAMURA and SHIMOZAWA, 1984). The cardiac resident phagocytes often had long cytoplasmic processes that were well developed toward the heart lumen and were highly endocytic for injected carbon particles, latex microspheres and SRBCs. Effete erythrocytes were sometimes observed in their cytoplasm, giving them the appearance of Kupffer cells of fish (SAKANO and FuJITA, 1982; TOMONAGA et al., 1986; HAMPTON et al., 1987) and mammals (WISSE et al., 1974; WiSSE, 1977).

The clearance of particulate substances from the blood may be an important function of the cardiac resident phagocytes in fish, similar to macrophages in the spleen and kidney (FERGUSON, 1989; ZAPATA and COOPER, 1990). Phagocytosis and degradation of aged and impaired blood cells are characteristic feature of macrophages in the spleen, liver and bone marrow of mammals. In addition, pulmonary intravascular macrophages are prominent sites of blood-cell degradation in the lungs of several mammals and humans (WARNER and BRAIN, 1986; WINKLER, 1988; ATWAL et al., 1992). Fish, however, usually have no hepatic Kupffer cells nor bone marrow and lungs. Resident phagocytes in spongy tissues of the fish heart may efficiently serve to clear the blood because the fish heart pumps blood directly into the systemic circulation without pulmonary circulation. Further studies are needed to clarify whether such cardiac resident phagocytes exist not only in fish but also in higher vertebrates whose hearts possess a pulmonary, circulatory machanism.

At present, nothing is known about the origin of cardiac resident phagocytes in fish. Recently, IsLAM et al. (1992) observed histologically that the endothelial cells of human bone marrow buldged out (sprouted out from their attachment to the basement membrane) and then budded off into the lumen of the blood vessel. Similar mechanisms of blood cell differentiation have also been observed in mammals (SMITH and GLOMSKI, 1982) and postembryonic stages of angelfish Pterophyllum scalare (AL-AdHAmi and KUNZ, 1976). Immunologic surface marker analyses and histochemical observations are needed to identify putative stem cells of the resident phagocytes, but unfortunately in the present study, plastic sectioning limited the possibility of immunological and histological methods. The fish heart can serve as a unique material in study of the reticuloendothelial system because of the associated phagocytic activity of endothelial cells and resident cell elements.

Acknowledgements. We would like to express our cordial thanks to Dr. E. L. COOPER, University of CaliforniaLos Angeles Medical Center, for critically reviewing the manuscript.

\section{REFERENCES}

Al-Adhami, M. A. and Y. W. Kunz: Haemopoietic centres in the developing angelfish Pterophyllum scalare (Cuvier and Valenciennes). Wilhelm Roux's Arch. 179: 393-401 (1976).

Andries, L. J. and D. L. Brutsaert: Differences in structure between endocardial and vascular endothelium. J. Cardiovasc. Res. 17 (Suppl. 3): S243-246 (1991).

- : Endocardial endothelium in the rat: cell shape and organization of the cytoskeleton. Cell Tiss. Res. 273: 107-117 (1993).

Atwal, O. S., B. Singh, H. Staempeli and K. Minhas: Presence of pulmonary intravascular macrophages in the equine lung: some structuro-functional properties. Anat. Rec. 234: 530-540 (1992).

Avtalion, R. R., A. Wojdani, Z. Malik, R. Shahrabani and M. DuCZYMiner: Influence of environmental temperature on the immune response in fish. Curr. Topics Microbiol. Immunol. 61: 1-35 (1973)

Brutsaert, D. L.: The endocardium. Annu. Rev. Physiol. 51: 263-273 (1989).

Brutsaert, D. L. and L. J. Andries: The endocardial endothelium. Amer. J. Physiol. 263 (H): 985-999 (1992). 
Ellis, A. E., A. L. S. Munroe and R. J. Roberts: Defense mechanisms in fish. J. Fish Biol. 8: 67-78 (1976).

Ferguson, H. W.: Phagocytosis by the endocardial lining cells of the atrium of plaice (Pleuronectes platessa). J. Comp. Pathol. 85: 561-569 (1975).

: Systemic pathology of fish. A text and atlas of comparative tissue responses in diseases of teleosts. Iowa State Univ. Press, Ames, 1989.

Fujita, T.: Microarchitecture of reticular tissues. Reevaluation of the RES by scanning electron microscopy. Recent Adv. RES Res. 18: 1-19 (1978).

Hampton, J. A., J. E. Klaunig and P. J. Goldblatt: Resident sinusoidal macrophages in the liver of the brown bullhead (Ictalurus nebulosus): an ultrastructural, functional and cytochemical study. Anat. Rec. 219: 338346 (1987).

Islam, A., C. Glomski and E. S. Henderson: Endothelial cells and hematopoiesis; A light microscopic study of fetal, normal, and pathologic human bone marrow in plastic-embedded sections. Anat. Rec. 233: 440-452 (1992).

KISCH, B.: On the significance of subendocardial cells as phagocytes. Exp. Med. Surg. 20: 55-64 (1962).

KushidA, H.: A new method for embedding with a low viscosity epoxy resin "Quetol 651". J. Electron Microsc. 23: 197 (1974).

Lamers, C. H. J. and H. K. Parmentier: The fate of intraperitoneally injected carbon particles in cyprinid fish. Cell Tiss. Res. 242: 499-504 (1985).

LEKNES, I. L.: Endocytosis of horse-spleen ferritin by bony fish endocardium. Acta Histochem. 81: 175-182 (1987).

Lemanski, L. F., E. P. Fitts and B. S. Marx: Fine structure of the heart in the Japanese medaka Oryzias latipes. J. Ultrastr. Res. 53: 37-65 (1975).

Lie, K. J., D. Heyneman and P. YAU: The origin of amebocytes in Biomphalaria glabrata. J. Parasitol. 63: 574-576 (1975).

Mackmull, G. and N. A. Michels: Absorption of colloidal carbon from the peritoneal cavity in the teleost, Tautogolabrus adspersus. Amer. J. Anat. 51: 3-47 (1932).

Melax, H. and T. S. LeEson: Fine structure of the endocardium in adult rats. Cardiovasc. Res. 1: 349-355 (1967).

Mori, M.: Studies on the phagocytic system in goldfish-I. Phagocytosis of intraperitoneally injected carbon particles. Fish Pathol. 15: 25-30 (1980).

Naito, M., T. Kodama, A. Matsumoto, T. Doi and K. Takahashi: Tissue distribution, intracellular localization, and in vitro expression of bovine macrophage scavenger receptors. Amer. J. Pathol. 139: 1411-1423 (1991).

Nakamura, H. and A. Shimozawa: Light and electron microscopic studies on the leucocytes of the medaka. Medaka 2: 15-21 (1984).

Nakamura, H., A. Shimozawa and S. Kikuchi: Melanomacrophage centre-like structure in the heart of the medaka, Oryzias latipes. Ann. Anat. 175: 59-63 (1993).

Overstreet, R. M. and J. Thulin: Response by Plectropomus leopardus and other serranid fishes to Pearsonellum conventum (Digenea: Sanguinicolidae), including melano- macrophage centres in the heart. Aust. J. Zool. 37: 129142 (1989).

Oya, M., T. Shimada, M. Nakamura and Y. UChida: Functional morphology of the lymphatic system in the monkey diaphragm. Arch. Histol. Cytol. 56: 37-47 (1993).

Sakano, E. and H. Fujita: Comparative aspects on the fine structure of the teleost liver. Okajima Fol. Anat. Jap. 58: 501-520 (1982).

Simer, P. H.: The passage of particulate matter from the peritoneal cavity into the lymph vessels of the diaphragm. Anat. Rec. 101: 333-351 (1934).

Smith, J, A., A. M. Shah and M. J. Lewis: Factors released from endocardium of the ferret and pig modulate myocardial contraction. J. Physiol. 439: 1-14 (1991).

Smith, R. A. and C. A. Glomski: "Hemogenic endothelium" of the embryonic aorta: does it exist? Devel. Comp. Immunol. 6: 359-368 (1982).

Takanashi, M. and M. Endoh: Characterization of positive inotropic effect of endothelin on mammalian ventricular myocardium. Amer. J. Physiol. 261 (Heart Circ. Physiol. 30): H611-H619 (1991).

Tomonaga, S., K. Yamaguchi, K. Ihara and K. Awaya: Mononuclear phagocytic cells (Kupffer cells) in hagfish liver sinusoids. Zool. Sci. 3: 613-620 (1986).

W ARner, A. E. and J. D. Brain: Intravascular pulmonary macrophages: a novel cell removes particles from blood. Amer. J. Physiol. 250: R728-R732 (1986).

Weinreb, E. L.: Studies on the fine structure of teleost blood cells, I. Peripheral blood. Anat. Rec. 147: 219-238 (1963).

WinkLER, G. C.: Pulmonary intravascular macrophages in domestic animal species: review of structural and functional properties. Amer. J. Anat. 181: 217-234 (1988).

WISSE, E.: Ultrastructure and function of Kupffer cells and other sinusoidal cells in the liver. In: (ed. by) E. WISSE and D. L. KNOOK: Kupffer cells and other liver sinusoidal cells. Elsevier/North-Holland Biomedical Press, Amsterdam, 1977 (p. 33-60).

Wisse, E., J. Meulen and J. M. Noordende: Observation on the fine structure and peroxidase cytochemistry of normal rat liver Kupffer cells. J. Ultrastr. Res. 46: 393-426 (1974).

ZaPATA, A. G. and E. L. Cooper: The bone marrow and its equivalents. In: (ed. by) A. G. ZAPATA and E. L. COOPER: The immune system: comparative histophysiology. John Wiley \& Sons, Chichester, 1990 (p. 35-67).

Dr. Hiroaki NAKAMURA
Department of Anatomy
Dokkyo University School of Medicine
Mibu, Tochigi
321-02 Japan
中 村 弘 明
321-02 栃木県下都賀郡壬生町北小林 880
獨協医科大学
第二解剖学教室

Dr. Hiroaki NAKAMURA

Dokkyo University School of Medicine Mibu, Tochigi

321-02 Japan

中 村 弘明

獨協医科大学

第二解剖学教室 